\title{
Study of The Adoption Aquaculture on Their Socio Economic Status.In Flds Under Krishi Vigyan Kendra Dewas, Madhya Pradesh, India
}

\author{
Ms. Nidhi Camble*, Dr. Sandhya Choudhary**,Dr. V.K. Swarnakar***. Dr. \\ Laxmi
}

\begin{abstract}
Studies revealed that the maximum profit from fish production can be achieved by adoption of proper recommended technology. Extent of adoption of the recommended fish production technology is one of the main reason contributing to low fish production. To improve the adoption of fish production technology, it is necessary to assess its level existing at actual situation. The perusal of data "overall average adoption of fish technology" revealed that out of the total fish farmers, the highest proportion of the fish farmers 36.67 per cent have adopted medium level of "overall average adoption of fish technology" technology before FLD's followed by low adoption 35.00 per cent and high adoption 28.33 per cent of "overall average adoption of fish technology" technology before FLD's respectively.
\end{abstract}

\section{INTRODUCTION}

Fishing in India is a major industry in its coastal states, employing over 14 million people. Fish production in India has increased more than tenfold since its independence in 1947. According to the Food and Agriculture Organization (FAO) of the United Nations, fish output in India doubled between 1990 and 2010. India is a major supplier of fish in the world. In 2006 the country exported over 600,000 metric tonnes of fish, to some 90 countries, earning over $\$ 1.8$ billion. Fisheries and aquaculture are important sources for food and livelihoods for people along the world's seashores and waterways and influence the livelihoods for long number of population. Fish production is not only an indispensable component of agriculture since long, but also the most suitable food production system that has enormous potential to improve the socio economic status of the large percentage of the rural population engaged in fishing business. India is the sixth largest producer (5477mt.) of fish in the world after China (39937 mt.), Peru (7878 mt.), Japan (7408 mt.), Chillie (6366 mt.) and USA (5493 mt.). The total world fish production is $130882 \mathrm{mt}$. India is the second largest producer in the world of inland fish, next to China. Indian fisheries have made great strides during last five decades with an annual production of about 7.0 million tonnes in 2013-14.

Fish farming is a lucrative business that can mitigate poverty in the country if practiced by adopting the necessary technologies. It requires less expand of land and it can be practiced in both rural and urban areas within the country. It also requires less time for its management and hence can be practiced by virtually everybody including the youths, house wives, working class and retirees. Studies revealed that the maximum profit from fish production can be achieved by adoption of proper recommended technology. Extent of adoption of the recommended fish production technology is one of the main reason contributing to low fish production. To improve the adoption of fish production technology, it is necessary to assess its level existing at actual situation. Keeping the above facts in mind, the present study was designed to conduct and formulated for the study with following objective.

Objective:

To study the adoption of aquaculture on their socio economic status.

\section{REVIEW OF LITERATURE}

Rao and Rao (2000) studied to assess the impact of aquaculture on the quality of lake water and on the lake ecosystem and on the lake ecosystem and also to assess the quality of water from fish ponds. An increase was recorded in the nutrients and heavy metal concentration in lake water which in turn would accumulate in the fish thus participating in the human food chain.

Reij and Bayer (2001) reported that farmers undertake innovations as a necessity driven by economy to earn the livelihood necessities. Hence, whatever knowledge farmers gain either from researchers or development agents are always tested and verified before integration into their farming operation. Even after integration, farmers continue innovation year after year in order to make sure that operation efficiency of the activity is improved and economic loss does not occur.

Mruthyunjaya (2004) reported that the fishermen head count ratio was found to below the poverty line was about 30 per cent, much higher than the national average of 26 per cent. The fishermen were found to be 
highly deficit in calories and protein. Fish technological development has been helped the fishermen in improving their income and social economic status and quality of life.

Carballo et al. (2008) reported that fish farming can be combined with agriculture, animal husbandry and irrigation practices, which can lead to better utilization of local resources and ultimately to higher production and net profits.

Ewoukem et al. (2012) studied the analysis of four farms that integrated fish farming with other agricultural production, and in which fish ponds were fertilized either by pig manure and /or crop by-products, in two regions of the western highlands of Cameroon. Dynamics of nitrogen $(\mathrm{N})$ and phosphorus $(\mathrm{P})$ were evaluated using a nutrient mass-balance modeling approach, which showed that low quantities of $\mathrm{N}$ and $\mathrm{P}$ were assimilated by the fish in these systems. Eutrophication impact was higher for these Cameroonian farms than that of other aquaculture system. Water and nutrient management will need to be improved to increase efficiency of these fish farms.

\section{METHODS AND MATERIAL}

For present study Krishi Vigyan Kendra (K.V.K.) Dewas was selected which is situated in Dewas district of Madhya Pradesh. According to the information obtained from K.V.K. Dewas, there was 9 villages have been adopted under the mandate of their programme and conducted FLDs of fish production technology. These FLDs villages of fish production were considered as representative of the study. A list of 9 villages under FLDs programme of KVK Dewas was prepared with their fish programme information. Out of these villages, only 6 villages have been selected for present study. 120 fishery farmers had been benefited by this programme in selected 6 villages under the KVK during 2010 to 2013. All the beneficiary farmers were is sample respondent for present study. Thus, the total 120 respondents as under FLDs programme of KVK were constitute the sample of the study.

IV. IMPACT OF TRAINING ON PRODUCTION TECHNOLOGY:

The impact of training on adoption of production technology by fish farmers was been measured by improvement in the extent of adoption as a result of the interventions of FLDs under Krishi Vigyan Kendra. The information on the status before and after the training was evaluated.

To measure the impact of training the fish farmers were asked to indicate their response for before and after the training as always, some time and never adopted the particular component of fish production technology and score 3, 2 and 1 was assigned, respectively.

The score obtained by the fish farmers for each statement was summed up to obtain the gain score. The adoption index was calculated by formula as follows:

\section{Adoption index $=\frac{\text { Actual score obtained by the fish farmers }}{X 100}$ \\ Maximum possible score}

To assess the change in adoption status due to impact of training, the fish farmers were categorized as low, medium and high based on Mean \pm S.D of total score.

\begin{tabular}{|c|c|c|}
\hline S.No. & Category & Score \\
\hline 1. & Low & Mean - S.D \\
\hline 2. & Medium & Mean \pm S.D. \\
\hline 3. & High & Mean +S.D. \\
\hline
\end{tabular}

Result \& Discussion

Distribution of the fish farmers according to extent of adoption of fish technology before and after FLD's.

\begin{tabular}{|c|c|c|c|c|c|c|c|}
\hline \multirow{2}{*}{ S.No. } & \multirow{2}{*}{ Fish technology } & \multicolumn{3}{|c|}{$\begin{array}{c}\text { Frequency } \\
\text { Before FLD's }\end{array}$} & \multicolumn{3}{|c|}{$\begin{array}{l}\text { Frequency } \\
\text { After FLD's }\end{array}$} \\
\hline & & $\begin{array}{c}\text { Low } \\
\text { adoption }\end{array}$ & $\begin{array}{l}\text { Medium } \\
\text { adoption }\end{array}$ & $\begin{array}{c}\text { High } \\
\text { adoption }\end{array}$ & $\begin{array}{c}\text { Low } \\
\text { adoption }\end{array}$ & $\begin{array}{l}\text { Medium } \\
\text { adoption }\end{array}$ & $\begin{array}{c}\text { High } \\
\text { adoption }\end{array}$ \\
\hline 1. & Pond management & & & & & & \\
\hline i. & $\begin{array}{l}\text { Testing of suitable } \\
\text { land for ponds }\end{array}$ & 48 & 41 & 31 & 29 & 45 & 46 \\
\hline ii. & $\begin{array}{l}\text { Ploughing of } \\
\text { ponds }\end{array}$ & 46 & 40 & 34 & 28 & 49 & 43 \\
\hline iii. & Cleaning of ponds & 45 & 37 & 38 & 31 & 45 & 44 \\
\hline iv. & $\begin{array}{l}\text { Proper } \\
\text { management of }\end{array}$ & 42 & 44 & 34 & 30 & 48 & 42 \\
\hline
\end{tabular}


Study of the adoption aquaculture on their socio economic status.

\begin{tabular}{|c|c|c|c|c|c|c|c|}
\hline & $\begin{array}{l}\text { water during } \\
\text { scarcity of rain }\end{array}$ & & & & & & \\
\hline v. & $\begin{array}{l}\text { Proper level of } \\
\text { water in ponds }\end{array}$ & 46 & 47 & 27 & 37 & 52 & 31 \\
\hline iv. & $\begin{array}{l}\text { Need for testing } \\
\text { the soil and water } \\
\text { of ponds }\end{array}$ & 40 & 47 & 33 & 33 & 50 & 37 \\
\hline & $\begin{array}{l}\text { Average of pond } \\
\text { management }\end{array}$ & $\begin{array}{c}44 \\
(36.67)\end{array}$ & $\begin{array}{c}43 \\
(35.83)\end{array}$ & $\begin{array}{c}33 \\
(27.50)\end{array}$ & $\begin{array}{c}31 \\
(25.83)\end{array}$ & $\begin{array}{c}48 \\
(40.00)\end{array}$ & $\begin{array}{c}41 \\
(34.17)\end{array}$ \\
\hline 2. & \multicolumn{7}{|c|}{ Selection of seed and management } \\
\hline i. & $\begin{array}{lr}\text { Selection } & \text { of } \\
\text { suitable } & \text { fish } \\
\text { variety as per local } \\
\text { condition }\end{array}$ & 38 & 51 & 31 & 25 & 55 & 40 \\
\hline ii. & $\begin{array}{lr}\text { Selection } & \text { of } \\
\text { suitable fish } & \text { seed } \\
\text { as per local } \\
\text { condition }\end{array}$ & 43 & 48 & 29 & 31 & 43 & 46 \\
\hline \multirow[t]{2}{*}{ iii. } & $\begin{array}{l}\text { Keep the number } \\
\text { of fish seed in a } \\
\text { particular area }\end{array}$ & 46 & 42 & 32 & 35 & 40 & 45 \\
\hline & $\begin{array}{l}\text { Average of } \\
\text { selection of seed } \\
\text { and management }\end{array}$ & $\begin{array}{c}42 \\
(35.00)\end{array}$ & $\begin{array}{c}47 \\
(39.17)\end{array}$ & $\begin{array}{c}31 \\
(25.83)\end{array}$ & $\begin{array}{c}30 \\
(25.00)\end{array}$ & $\begin{array}{c}46 \\
(38.33)\end{array}$ & $\begin{array}{c}44 \\
(36.67)\end{array}$ \\
\hline 3. & \multicolumn{7}{|c|}{ Feed and fertilizer management } \\
\hline i. & $\begin{array}{lr}\begin{array}{l}\text { Management } \\
\text { natural }\end{array} \\
\text { availability for fish }\end{array}$ & 38 & 43 & 39 & 27 & 48 & 45 \\
\hline ii. & $\begin{array}{l}\text { Providing types } \\
\text { and kinds of } \\
\text { supplementary } \\
\text { foods }\end{array}$ & 33 & 46 & 41 & 22 & 44 & 54 \\
\hline iii. & $\begin{array}{l}\text { Providing } \\
\text { supplementary } \\
\text { food in proper } \\
\text { quantity }\end{array}$ & 36 & 37 & 47 & 26 & 37 & 57 \\
\hline \multirow[t]{2}{*}{ iv } & $\begin{array}{l}\text { Application of } \\
\text { chemicals for } \\
\text { enhancing yield of } \\
\text { fish }\end{array}$ & 41 & 45 & 34 & 33 & 40 & 47 \\
\hline & $\begin{array}{l}\text { Average of feed } \\
\text { and fertilizer } \\
\text { management }\end{array}$ & $\begin{array}{c}37 \\
(\mathbf{3 0 . 8 3})\end{array}$ & $\begin{array}{c}43 \\
(35.83)\end{array}$ & $\begin{array}{c}40 \\
(33.34)\end{array}$ & $\begin{array}{c}27 \\
(22.50)\end{array}$ & $\begin{array}{c}42 \\
(35.00)\end{array}$ & $\begin{array}{c}51 \\
(42.50)\end{array}$ \\
\hline 4. & \multicolumn{7}{|c|}{ Unwanted fishes and weed management } \\
\hline i. & $\begin{array}{lr}\text { Removal } & \text { of } \\
\text { undesired } & \text { variety } \\
\text { of fish from ponds }\end{array}$ & 47 & 42 & 31 & 33 & 47 & 40 \\
\hline ii. & $\begin{array}{l}\text { Application of } \\
\text { bleaching powder }\end{array}$ & 46 & 48 & 26 & 33 & 47 & 40 \\
\hline iii. & $\begin{array}{l}\text { Control of weed in } \\
\text { ponds }\end{array}$ & 43 & 49 & 28 & 34 & 52 & 34 \\
\hline \multirow[t]{2}{*}{ iv. } & $\begin{array}{l}\text { Control of hunting } \\
\text { fish in ponds }\end{array}$ & 44 & 47 & 29 & 34 & 53 & 33 \\
\hline & $\begin{array}{lr}\begin{array}{l}\text { Average } \\
\text { unwanted }\end{array} & \text { of } \\
\text { fishes } \\
\text { and } & \text { weed } \\
\text { management }\end{array}$ & $\begin{array}{c}45 \\
(37.50)\end{array}$ & $\begin{array}{c}46 \\
(38.33)\end{array}$ & $\begin{array}{c}29 \\
(24.17)\end{array}$ & $\begin{array}{c}33 \\
(27.50)\end{array}$ & $\begin{array}{c}50 \\
(41.67)\end{array}$ & $\begin{array}{c}37 \\
(\mathbf{3 0 . 8 3})\end{array}$ \\
\hline 5. & \multicolumn{7}{|c|}{ Fish protection management } \\
\hline
\end{tabular}


Study of the adoption aquaculture on their socio economic status.

\begin{tabular}{|c|c|c|c|c|c|c|c|}
\hline i. & $\begin{array}{l}\text { Security against } \\
\text { damage of fish } \\
\text { through insect and } \\
\text { other } \\
\text { organism }\end{array}$ & 46 & 42 & 32 & 35 & 40 & 45 \\
\hline ii. & $\begin{array}{l}\text { Cure of fish } \\
\text { against disease }\end{array}$ & 41 & 45 & 34 & 33 & 40 & 47 \\
\hline & $\begin{array}{l}\text { Average of fish } \\
\text { protection } \\
\text { management }\end{array}$ & $\begin{array}{c}44 \\
(36.67)\end{array}$ & $\begin{array}{c}43 \\
(35.83)\end{array}$ & $\begin{array}{c}33 \\
(\mathbf{2 7 . 5 0})\end{array}$ & $\begin{array}{c}34 \\
(28.33)\end{array}$ & $\begin{array}{c}40 \\
(33.33)\end{array}$ & $\begin{array}{c}46 \\
(38.34)\end{array}$ \\
\hline 6. & \multicolumn{7}{|c|}{ Harvesting and storage } \\
\hline i. & $\begin{array}{l}\text { Catching of fish } \\
\text { after proper } \\
\text { duration of time }\end{array}$ & 40 & 45 & 35 & 26 & 50 & 44 \\
\hline ii. & $\begin{array}{lr}\text { Most } & \text { suitable } \\
\text { method of fish } \\
\text { catching }\end{array}$ & 36 & 42 & 42 & 26 & 46 & 48 \\
\hline \multirow[t]{2}{*}{ iii } & $\begin{array}{l}\text { Suitable storage } \\
\text { time between } \\
\text { harvesting and } \\
\text { marketing of fish }\end{array}$ & 39 & 44 & 37 & 27 & 46 & 47 \\
\hline & $\begin{array}{lr}\begin{array}{l}\text { Average } \\
\text { harvesting } \\
\text { storage }\end{array} & \begin{array}{r}\text { of } \\
\text { and }\end{array} \\
\end{array}$ & $\begin{array}{c}38 \\
(31.67)\end{array}$ & $\begin{array}{c}44 \\
(36.66)\end{array}$ & $\begin{array}{c}38 \\
(31.67)\end{array}$ & $\begin{array}{c}27 \\
(22.50)\end{array}$ & $\begin{array}{c}47 \\
(39.17)\end{array}$ & $\begin{array}{c}46 \\
(38.33)\end{array}$ \\
\hline 7. & $\begin{array}{c}\text { Overall average } \\
\text { adoption of fish } \\
\text { technology }\end{array}$ & $\begin{array}{c}42 \\
(35.00)\end{array}$ & $\begin{array}{c}44 \\
(36.67)\end{array}$ & $\begin{array}{c}34 \\
(28.33)\end{array}$ & $\begin{array}{c}30 \\
(25.00)\end{array}$ & $\begin{array}{c}46 \\
(38.33)\end{array}$ & $\begin{array}{c}44 \\
(36.67)\end{array}$ \\
\hline
\end{tabular}

Figure in parentheses shows percentage of total

The above Table describes the distribution of fish farmers as per the level of adoption of major fish technology before and after FLD's.

\section{Adoption of pond management:}

The perusal of data "regarding pond management" revealed that out of the total fish farmers, the highest proportion of the fish farmers 36.67 per cent have adopted low level of "pond management" technology before FLD's followed by medium adoption 35.83 per cent and high adoption 27.50 per cent of "pond management" technology before FLD's respectively. On the other hand, out of the total fish farmers, the highest proportion of the fish farmers 40.00 per cent have adopted medium level of "pond management" technology after FLD's followed by high adoption 34.17 per cent and low adoption 25.83 per cent of "pond management" technology after FLD's respectively.

\section{Adoption of selection of seed and management:}

The perusal of data "regarding selection of seed and management" revealed that out of the total fish farmers, the highest proportion of the fish farmers 39.17 per cent have adopted medium level of "selection of seed and management" technology before FLD's followed by low adoption 35.00 per cent and high adoption 25.83 per cent of "selection of seed and management" technology before FLD's respectively. On the other hand, out of the total fish farmers, the highest proportion of the fish farmers 38.33 per cent have adopted medium level of "selection of seed and management" technology after FLD's followed by high adoption 36.67 per cent and low adoption 25.00 per cent of "selection of seed and management" technology after FLD's respectively.

\section{Adoption of feed and fertilizer management:}

The perusal of data "regarding feed and fertilizer management" revealed that out of the total fish farmers, the highest proportion of the fish farmers 35.83 per cent have adopted medium level of "feed and fertilizer management" technology before FLD's followed by high adoption 33.34 per cent and low adoption 30.83 per cent of "feed and fertilizer management" technology before FLD's respectively. On the other hand, out of the total fish farmers, the highest proportion of the fish farmers 42.50 per cent have adopted high level of "feed and fertilizer management" technology after FLD's followed by medium adoption 35.00 per cent and low adoption 22.50 per cent of "feed and fertilizer management" technology after FLD's respectively. 


\section{Adoption of unwanted fishes and weed management:}

The perusal of data "regarding unwanted fishes and weed management" revealed that out of the total fish farmers, the highest proportion of the fish farmers 38.33 per cent have adopted medium level of "unwanted fishes and weed management" technology before FLD's followed by low adoption 37.50 per cent and high adoption 24.17 per cent of "unwanted fishes and weed management" technology before FLD's respectively.In the total fish farmers, the highest proportion of the fish farmers 41.67 per cent have adopted medium level of "unwanted fishes and weed management" technology after FLD's followed by high adoption 30.83 per cent and low adoption 27.50 per cent of "unwanted fishes and weed management" technology after FLD's respectively.

\section{Adoption of fish protection management:}

The perusal of data "regarding fish protection management" revealed that out of the total fish farmers, the highest proportion of the fish farmers 36.67 per cent have adopted low level of "fish protection management" technology before FLD's followed by medium adoption 35.83 per cent and high adoption 27.50 per cent of "fish protection management" technology before FLD's respectively. In case of the total fish farmers, the highest proportion of the fish farmers 38.34 per cent have adopted high level of "fish protection management" technology after FLD's followed by medium adoption 33.33 per cent and low adoption 28.33 per cent of "fish protection management" technology after FLD's respectively.

\section{Adoption of harvesting and storage:}

The perusal of data "regarding harvesting and storage" revealed that out of the total fish farmers, the highest proportion of the fish farmers 36.66 per cent have adopted medium level of "harvesting and storage" technology before FLD's followed by low adoption 31.67 per cent and high adoption 31.67 per cent of "harvesting and storage" technology before FLD's respectively.

On the other hand, out of the total fish farmers, the highest proportion of the fish farmers 39.17 per cent have adopted medium level of "harvesting and storage" technology after FLD's followed by high adoption 38.33 per cent and low adoption 22.50 per cent of "harvesting and storage" technology after FLD's respectively.

\section{Overall average adoption of fish technology:}

The perusal of data "overall average adoption of fish technology" revealed that out of the total fish farmers, the highest proportion of the fish farmers 36.67 per cent have adopted medium level of "overall average adoption of fish technology" technology before FLD's followed by low adoption 35.00 per cent and high adoption 28.33 per cent of "overall average adoption of fish technology" technology before FLD's respectively. Where as out of the total fish farmers, the highest proportion of the fish farmers 38.33 per cent have adopted medium level of "overall average adoption of fish technology" technology after FLD's followed by high adoption 36.67 per cent and low adoption 25.00 per cent of "overall average adoption of fish technology" technology after FLD's respectively.

\section{Adoption behaviour of fish farmers before and after the FLD's:}

It is fact that in general; farmers learn about new technologies and practices from various organizations, programmes and projects dedicated to research, extension, or rural development. The KVK personnel of Dewas are one of the leading organization who have conducted many extension activities and FLD's in respect of improved fish production technology. This organization makes efforts to train the fish farmers in adoption of improved management practices. For further improvement in this type of extension activities and motivational factors of FLD's programme, it is essential that such organization be able to follow the results of their efforts and understand how the technologies they exhibited fit into the complex pattern of situational change in which all fish farmers practice. In this respects the present study revealed that, out of the total fish farmers the highest proportion of the fish farmers have adopted medium level of "overall average adoption of fish technology" technology after FLD's followed by high adoption and low adoption of "overall average adoption of fish technology" technology after FLD's respectively. The medium adoption might be due to the fact that fish farmers, had the tendency towards efficient working but due to several constraints affects in injudicious use of inputs and practices. Improvement of technical skill and faith might result of these improved practices and technology they adopted medium level of various component of improved fish production practices.

\section{REFERENCE}

[1] Carballo,Eira.; Eer,Assiah Van; Schie,Ton Van and Hilbrands,Aldin (2008). Small-scale freshwater fish farming. Agromisa Foundation and CTA, Wageningen. 
[2] Ewoukem,T.E.; Aubin,J.; Mikolasek,O.; Corson,M.S.; Eyango,M.T.; Tchouboue,J.; Werf.H.M.G, and Van,Der Omdredance,D. (2012). Environment impacts of farm integrating aquaculture and agriculture in Cameroon. Journal of Cleaner Production. 28:208-214.

[3] Fagbenro,O.A. (2005). Aquaculture in Nigeria: history, status and prospects. A report of FAO World Fish Centre Workshop. Cameroon.

[4] Mruthyunjaya (2004). Strategies and options for increasing and sustaining fisheries and aquaculture production to benefit poor households in India. National Centre for Agricultural Economics and Policy Research New Delhi, India.

[5] Reij,C. and Bayer,A.W. (2001). Farmer Innovation in Africa, Earthscan Publications Ltd., London. pp:362.

[6] Roger,E.M. (2003). Diffusion of Innovations. (5 ${ }^{\text {th }}$ edition) free Press New York.

i. M.Sc. Students 2015, College of Agriculture, Indor

ii. $\quad * *$ Associate Professor, College of Agriculture, Indore

iii. $\quad * * *$ Professor \& Head of Extension Education, College of Agriculture, Indore

1. $\quad * * * *$ SMS Krishi Vigyan Kendra, Dewas 